\title{
Áldozatvédelem vagy tényleges bizonyítás? A fordított bizonyítási teher megítélése a foglalkozási diszkriminációs ügyek hazai gyakorlatában
}

\author{
bizonyítási teher - diszkrimináció - egyenlő bánásmód követelménye - \\ valószínüsités
}

\begin{abstract}
A diszkriminációs ügyekben alkalmazott fordított bizonyítási eljárás jelentősége, hogy a bizonyítási teher osztott. A munkavállalónak valószínüsítenie kell, hogy valamely védett tulajdonságára tekintettel hátrányos megkülönböztetés érte a munkáltató részéről, ${ }^{1} \mathrm{~s}$ meg is kell jelölnie ezen védett tulajdonságát. Ezt követően a munkáltató kimentési lehetőségeit vizsgálják meg.

A diszkriminációs ügyekben alkalmazandó speciális bizonyítási szabályokat a diszkriminációs ügyek „szívének” is nevezhetjük, hiszen végeredményben a bizonyítási eljáráson, ebből adódóan pedig annak speciális szabályain múlik a diszkrimináció tilalmát érvényre juttató szabályok hatékonysága. ${ }^{2}$ Azaz az antidiszkriminációs szabályozás és gyakorlat megfelelőségét, illetve eredményességét leronthatja az olyan jogértelmezés, amely nincs kellő mértékben tekintettel az egyenlő bánásmód elvének megsértése esetén alkalmazandó szabályok lényegére és jelentőségére. A tanulmány alapjául szolgáló jogi problémák elsődlegesen az általában elfogadott bizonyítási szabályok és a diszkriminációs ügyekben alkalmazandó „fordított” bizonyítás alapvető elméleti és gyakorlati szembenállása miatt merülnek fel. Értelemszerüen ez meg is nehezíti e szabályok jogalkalmazó általi akceptálását és értelmezését. E speciális bizonyítási szabályok nem megfelelő értelmezése, ad absurdum negligálása ugyanakkor az egyenlő bánásmód elvének megsértése esetén alkalmazandó hatékony jogorvoslati lehetőségek ${ }^{3}$ meggyengüléséhez vezethet.
\end{abstract}

* Dr. Zaccaria Márton Leó egyetemi tanársegéd, Debreceni Egyetem Agrárjogi, Környezetjogi és Munkajogi Tanszék, zaccaria.marton@law.unideb.hu.

1 GyulaVÁRı Tamás: Egyenlők és egyenlőbbek (8. rész). Humán Szaldó, 2009/10, 263-265.

2 GYulavÁRI Tamás: Burden of Proof: Differing ways of shifting the obligations? The Hungarian Labour Law in the Light of the European Labour Law - Development, Compulsion and Opportunity (konferencia), Pécsi Tudományegyetem Állam- és Jogtudományi Kar, MTA-PTE Research Group of Comparative and European Employment Policy and Labour Law, Pécs, 2014. 10. 14.

3 Lásd az Európai Parlament és a Tanács 2006/54/EK irányelvének 17. és 18., a 2000/78/EK tanácsi irányelv 9. és a 2000/43/EK tanácsi irányelv 7 . cikkét. 
A következő néhány oldalban a fordított - más néven osztott - bizonyítási teher ${ }^{4}$ szabályozási háttere és gyakorlata kerül elemzésre, amelyek a magyar joggyakorlat alapján különös jelentőséggel bírnak, és alapvető kihatással vannak a munkáltató szük körben értelmezett kimentési lehetőségeire.

A tanulmányban különös figyelmet fordítunk a nem egységes, söt ellentmondásos magyar jogértelmezés feltárására. Jelen írás kiindulópontja az, hogy a látszólag egyértelmú szabályozás ellenére a magyar jogalkalmazás két ága - vagyis az Egyenlő Bánásmód Hatóság és a Kúria gyakorlata - e szabályok értelmezése során eltérő nézőpontokat képvisel. A tanulmányban annak feltárására vállalkozunk, hogy melyik értelmezés felel meg jobban a szabályozás valódi céljának. Ezek alapján pedig arra nézve vonunk le következtetést, hogy a magyar joggyakorlatban a diszkriminációt elszenvedett fél érdekei kerülnek-e előtérbe (áldozatvédő szemlélet), vagy más szempontok dominálnak az értelmezésben.

\section{Az Ebktv. szigorú szabályozása}

Elsőként célszerüen az egyenlő bánásmódról és az esélyegyenlőség előmozdításáról szóló 2003. évi CXXV. törvényben (a továbbiakban: Ebktv.) foglalt szabályokat tekintjük át, ugyanis ezek elemzése nélkül nehezen érthetőek meg a felmerülö gyakorlati problémák. Az Ebktv. szabályozása gyakorlatilag megfelel az uniós jogban foglaltaknak, így utóbbi szabályozási sarokpontjait csak röviden érintjük.

Az európai uniós szabályozás és joggyakorlat máig az azóta hatályon kívül helyezett 97/80/EK irányelv által megteremtett keretek között mozog, azonban az egyre változatosabb és összetettebb bírósági eseteknek köszönhetően ez a gyakorlat folyamatosan formálódik. ${ }^{5} \mathrm{~A}$ jelenleg hatályos uniós szabályozás az egyenlő bánásmód elvét védett tulajdonságonként szabályozza a 2006/54/EK, 2000/78/EK és 2000/43/EK irányelvekben. ${ }^{6}$ Tekintettel arra, hogy ezen irányelvek jogvédelmi me-

4 Palmer álláspontja szerint nem teljesen helyes a fordított bizonyítási teher kifejezés használata, ugyanis maga a bizonyítási teher tartalmilag nem fordul meg, mindössze a bizonyitás sorrendjében és az igazolás szintjében következik be változás az irányelvi elöírások alapján. Ez alapján helyesebb volna "megcserélt”, „felcserélt”, „áthárított”, esetleg „váltott” bizonyítási teherként definiálni azt az Ebktv.-ben. Lásd PALMER, Fiona: Re-dressing the Balance of Power in Discrimination Cases: The Shift in the Burden of Proof. European Anti-Discrimination Law Review, 2006/4, 26.

5 Lásd az Európai Unió Bíróságának joggyakorlatából a legfontosabb eseteket: a Bíróság 2013. április 25-i ítélete a C-81/12. sz., Asociaţia ACCEPT kontra Consiliul Naţional pentru Combaterea Discriminării ügyben (ECLI:EU:C:2013:275), a Bíróság 2012. április 19-i ítélete a C-415/10. sz., Galina Meister kontra Speech Design Carrier Systems GmbH ügyben (ECLI:EU:C:2012:217), a Bíróság 2011. július 21-i ítélete a C-104/10. sz., Patrick Kelly kontra National University of Ireland (University College, Dublin) ügyben (ECLI:EU:C:2011:506) és a Bíróság 2008. július 10-i ítélete a C-54/07. sz., Centrum voor gelijkheid van kansen en voor racismebestrijding kontra Firma Feryn NV ügyben (ECLI:EU:C:2008:397). Említhető néhány példa a Bíróság legújabb gyakorlatából is: a Bíróság 2015. július 9-i ítélete a C-177/14. sz., María José Regojo Dans kontra Consejo de Estado ügyben (ECLI:EU:C:2015:450) és a Bíróság 2014. december 18-i ítélete a C-354/13. sz., Fag og Arbejde (FOA) kontra Kommunernes Landsforening (KL) ügyben (ECLI:EU:C:2014:2463).

6 Lásd: 2006/54/EK irányelv 19. cikk (1) bekezdés, 2000/78/EK irányelv 10. cikk (1) bekezdés és 2000/43/EK irányelv 8 . cikk (1) bekezdés. 
chanizmusa nagyon hasonló egymáshoz, a bizonyítási teher előirásai lényegében mindhárom irányelvben azonosak.

A bizonyítási teher eredeti szabályait tartalmazó 97/80/EK irányelv kifejezetten a nemi alapú diszkrimináció esetére fogalmazta meg a bizonyítási teher megosztásának normáit. Erre tekintettel - a védett tulajdonságok körének kibővülése mellett - abban a tekintetben is tovább fejlödött a szabályozás, hogy a fordított bizonyitási teher gerincét jelentő felperesi valószínüsitési és alperesi (ellen)bizonyitási kötelezettséget markánsabban választja el egymástól. Így egyértelmüen rögzítésre kerül, hogy a felperesnek mindössze valószínüsítési, nem pedig bizonyítási kötelezettsége van. ${ }^{7}$

A magyar jogban az egyenlö bánásmód követelményének megsértése esetén indítható eljárásokra vonatkozó speciális szabályokat az Ebktv. 19. §-a tartalmazza. Fontos, hogy az Ebktv. az általános bizonyitási szabályoktól eltérő rendelkezéseket kimerítő jelleggel rögzíti, vagyis azokat valamennyi ilyen tárgyú eljárás esetén érvényesíteni kell. ${ }^{8} \mathrm{~A}$ bizonyítás szabályai osztottak, és ez az osztottság nem csupán mennyiségi, hanem minőségi különbséget is jelöl a felek között, hiszen gyakorlatilag a sérelmet szenvedett fél valószínűsítési kötelezettsége áll szemben a sérelmet okozó fél szigorú bizonyítási kötelezettségével. Ez a fajta felosztás érvényre juttatja az uniós elöírások között rögzített ${ }^{9}$ azon fontos elvet, miszerint diszkriminációs ügyekben az erősebb pozícióban lévő fél oldalára kell helyezni a bizonyítási terhet, vagyis arra, aki a diszkrimináció „forrása”, okozója és birtokában van valamennyi releváns ténynek, körülménynek. ${ }^{10}$ Ez egyben azt is jelenti, hogy a kedvezményes bizonyitási szabályokat úgy kell kialakitani, hogy azok a sérelmet szenvedett fél érdekeit szolgálják, hiszen az ő helyzete egy ilyen eljárás során nehezebb. ${ }^{11}$ Ezen túl a jogsérelem jellege alapján is indokolt könnyebb helyzetbe hozni az eljárást kezdeményező felet. ${ }^{12}$

7 A 97/80/EK tanácsi irányelv 4. cikk (1) bekezdése szerint „[a] tagállamok, nemzeti bírósági rendszerükkel összhangban, megteszik a szükséges intézkedéseket annak érdekében, hogy az alperes legyen köteles azt bizonyítani, hogy az egyenlö bánásmód elvét nem sértették meg, amennyiben valaki úgy ítéli meg, hogy az egyenlö bánásmód elvének alkalmazásának elmulasztása miatt sérelmet szenvedett és bíróság vagy más illetékes hatóság elött olyan tényekre hivatkozik, amelyekböl közvetlen vagy közvetett megkülönböztetésre lehet következtetni”. Eme alapvetö különbség valószínüsítés és bizonyítás között az alapja a felperesre nézve kedvezményes bizonyítási szabályoknak a diszkriminációs ügyekben.

8 GyulaváRı Tamás: Egyenlő bánásmód törvény - célok és eredmények. In: Majtényi Balázs (szerk.): Lejtős pálya - Antidiszkrimináció és esélyegyenlőség. L'Harmattan, Budapest, 2009, 17-20.

9 O’Leary ezzel összefüggésben arra is felhívja a figyelmet, hogy a bizonyítási szabályok - kiemelve, hogy a munkáltató kimentési bizonyításának objektív alapúnak kell lennie - egyúttal a közvetett hátrányos megkülönböztetés joggyakorlatának megszilárdításában is fontos szerepet játszanak, különösen a nemi alapú diszkrimináció vonatkozásában. Lásd O'LEARY, Síofra: Employment Law at the European Court of Justice. Judicial Structures, Policies and Processes. Hart Publishing, Oxford-Portland Oregon, 2002, 151.

10 Tobler, Christa: A Case Study into the Development of the Legal Concept of Indirect Discrimination under EC Law. Intersentia, Antwerpen-Oxford, 2005, 73, 252 és 280-281.

11 Értve ez alatt a bizonyítandó tények körét, ezek ugyanis jellemzően nincsenek a felperes birtokában. Lásd Cunningham, Naomi: Discrimination Through the Looking-glass: Judicial Guidelines on the Burden of Proof. Industrial Law Journal, 2006/3, 272-278.

12 Palmer: i. m., 23-25. 
A sérelmet szenvedett fél valószínüsitési kötelezettsége kétirányú, amely követelmények azonban - az Ebktv. 19. § (1) bekezdés a) és b) pontja szerint - konjunktívak. Ennek megfelelően a sérelmet szenvedett személynek vagy csoportnak valószínüsítenie kell, hogy hátrány érte, és azt, hogy rendelkezik valamely, az Ebktv. 8. $\S$-ában meghatározott védett tulajdonsággal. Valószínüsítés alatt olyan bizonyítást kell érteni, amely alapján az átlagember azt a következtetést vonja le, hogy objektív megítélés alapján a kérelmező panasza alapos. ${ }^{13}$ Így sikeres a valószínüsítés akkor, ha a munkavállaló annak látszatát kelti, hogy azért részesül kevesebb munkabérben, mint a kollégái, mert nő, míg a kollégák férfiak. ${ }^{14} \mathrm{~A}$ b) pont további eligazítást ad a védett tulajdonság kapcsán, ugyanis a megjelölt védett tulajdonságnak a jogsértés időpontjában kell fennállnia, vagyis abból a szempontból is ténylegesnek kell lennie, hogy nem elég, ha azzal a panaszos egy jogsértést megelőző időpontban rendelkezett. Fontos továbbá az is, hogy a sérelmet szenvedett félnek vagy ténylegesen kell rendelkeznie a védett tulajdonsággal, vagy pedig a jogsértő fél feltételezése szerint. ${ }^{15}$ Elöbbi nem szorul magyarázatra, hiszen értelemszerűen fogalmilag lesz sikertelen a valószínüsítés abban az esetben, ha a panaszos úgy érzi, hogy „valamilyen” okból sújtja hátránnyal munkáltatója, de ez nem védett tulajdonságon alapszik. ${ }^{16}$ Ugyanez a helyzet áll elő akkor, ha a munkavállaló valóban rendelkezik valamilyen védett tulajdonsággal, azonban az nem az Ebktv. 8. § szerinti védett tulajdonság. ${ }^{17}$ Megjegyzendő, hogy amennyiben valóban rendelkezik valamilyen védett tulajdonsággal a jogában vélt vagy valós sérelmet szenvedett fél, de az Ebktv. szerinti hátrány nem ezen a tulajdonságán alapszik, szintén nem lehet hátrányos megkülönböztetést megállapítani. Ugyanakkor az Ebktv. 8. § t) pontja szerinti egyéb helyzet természetesen védett tulajdonságnak minősül ebben az értelemben is. Végeredményben az oksági kapcsolat bizonyitása már nem a felperes vagy panaszos feladata, hanem a munkáltatónak van lehetősége annak hiányát bizonyítani sikeres valószínüsítés esetén. ${ }^{18}$

Az említett osztott bizonyítási teher szabályának megfelelöen az (1) bekezdés szerinti valószínűsités sikeressége esetén a munkáltatónak kell bizonyítania, hogy a munkavállaló által valószínüsített körülmények valójában nem állnak fenn, ${ }^{19}$ vagy

${ }_{13}$ A 2006/54/EK irányelv 19. cikk (1) bekezdése szerint a panaszosnak - felperesnek - „...olyan tényekre kell hivatkozni, amelyekböl közvetlen vagy közvetett hátrányos megkülönböztetésre lehet következtetni" (az eredeti angol nyelvű változatban: „... from facts which it may be presumed...."). Ezzel szemben az eljárás alá vont - az alperes - „....köteles azt bizonyítani, hogy az egyenlő bánásmód elvét nem sértette meg....” (,...it shall be for the respondent to prove...”). Áláspontunk szerint a megfogalmazásbeli különbségböl is látszik, hogy a hivatkozás-valószínüsítés érdemben eltér a bizonyítástól. Az angol nyelvű változatból még inkább ez következik, tekintettel a „presume” és „prove” igék közötti jelentős tartalombeli különbségre.

14 Lásd például az Egyenlö Bánásmód Hatóság 577/2013. számú határozatát.

15 A feltételezéssel kapcsolatban lásd GYULAVÁRI Tamás-KÁDÁR András Kristóf: A magyar antidiszkriminációs jog vázlata. Bíbor, Miskolc, 2009, 65-70.

16 Lásd 540/2008., 1869/2009. és 759/2009. számú EBH határozatok, melyek szerint a panaszos mindössze a munkáltatóval megromlott munkakapcsolatát jelölte meg a megkülönböztetés alapjaként.

17 Tipikusan azok az esetek sorolhatók ide, melyek során a kérelmező vagy a felperes az Ebktv. 8. § t) pontját jelöli meg védett tulajdonságként.

12618 Legalábbis az idézett irányelvi elöirásokból álláspontunk szerint ez következik.

19 Ebktv. 19. § (2) bekezdés a) pont. 
azt, hogy az egyenlő bánásmód követelményét megtartotta, vagy pedig azt nem volt köteles megtartani. ${ }^{20}$ Ezek tehát nem konjunktív feltételek, hanem három jól körülhatárolható, eltérő eset jelenik meg az Ebktv.-ben. Álláspontunk szerint az Ebktv. 19. $\S(2)$ bekezdés $b$ ) pontja szerinti kimentési ok is feltételezi a sikeres valószínűsítést, hiszen annak hiányában hátrányos megkülönböztetésröl fogalmilag nem is beszélhetünk, mivel eltérő esetben a munkáltatónak nem lenne mi alól kimentenie magát.

\section{Az Egyenlő Bánásmód Hatóság áldozatfókuszált jogértelmezése}

Szükséges kitérni az Egyenlő Bánásmód Tanácsadó Testület 384/4/2008. (III. 28.) számú állásfoglalására, amely részletekbe menően foglalkozik a bizonyitási teher megosztásának szabályaival. Itt részletesen elemzésre kerül az, hogy mit jelent a panaszos valószínüsítési kötelezettsége és az, hogy az egyenlő bánásmód elvét megsértőnek milyen bizonyitási lehetőségek állnak rendelkezésre a kimentés vonatkozásában. Az állásfoglalás az Ebktv.-ben foglaltakat hivatott kiegészíteni és értelmezni, így elősegítve a joggyakorlat fejlesztését és egységesítését. Az állásfoglalás az Egyenlő Bánásmód Hatóság joggyakorlatában kikristályosodott gyakorlatát tartalmazza, és az abban foglaltakat a Hatóság egyedi határozataiban következetesen érvényre is juttatja.

Az állásfoglalás szerint a munkáltatóra vonatkozó kimentési-bizonyitási szabályok funkciója az, hogy egy ex lege megdönthető vélelemmel szemben igazolhatóvá váljon az, hogy az egyenlő bánásmód elve nem sérült. ${ }^{21} \mathrm{~A}$ törvény logikája szerint ugyanis az Ebktv. 19. § (1) bekezdése szerinti sikeres valószínüsítés esetén vélelmezni kell az egyenlő bánásmód elvének megsértését, azonban ez a vélelem megdönthető. Ugyanakkor sikeres kimentési bizonyítás esetén sem biztos, hogy a munkáltató igazolni tudja, hogy megtartotta az egyenlő bánásmód elvét, hiszen az állásfoglalás szerint a bizonyítási eljárás következő - egyben utolsó - lépéseként a jogában megsértett félnek lehetősége van arra, hogy megcáfolja a jogsértő fél által kimentési bizonyításként előadottakat. Egyetértve az állásfoglalással, azért tartom indokoltnak a sérelmet szenvedett félre nézve többszörösen kedvező szabályok alkalmazását, mert így kompenzálható a bizonyitékokhoz való hozzájutásból származó hátrány, hiszen azokkal elsődlegesen a jogsértő fél rendelkezik. ${ }^{22}$

Az állásfoglalás részletesen kifejti, hogy mit kell a fentebb említett kimentési okok alatt érteni, így érdemes ezeket röviden áttekinteni. Az első esetben az eljárás alá vont azt bizonyítja, hogy a másik fél által valószínūsített körülmények nem állnak fenn. Ekkor a tényállás szintje nem éri el a diszkrimináció szintjét. A második esetben azzal tudja igazolni, hogy megtartotta az egyenlő bánásmód követelményét, hogy a bekövetkezett hátrány és a védett tulajdonság között hiányzik az okozati összefüggés. A harmadik esetben pedig irreleváns az, hogy az Ebktv. szerinti tényállási elemek közül melyek valósulnak meg, ugyanis ekkor az eljárás alá vont azt

20 Ebktv. 19. § (2) bekezdés b) pont.

384/4/2008. (III. 28.) TT. sz. állásfoglalás a bizonyítási kötelezettség megosztásával kapcsolatban.

22 Cunningham: i. m., 272-278. 
tudja igazolni, hogy az egyenlő bánásmód elvét - általános vagy ágazati szabály alapján - nem volt köteles megtartani, vagyis magatartásától függetlenül mentesül a diszkrimináció megállapítása alól.

Fontos megállapitása továbbá az állásfoglalásnak, hogy a hátrány és a védett tulajdonság közötti oksági kapcsolat bizonyitása nem a sérelmet szenvedett fél kötelessége, hanem a Hatóságé vagy bíróságé. Egyúttal a munkáltatónak természetesen lehetősége van az ok-okozati összefüggés hiányát bizonyítani. Rögzíteni kell tehát, hogy az Ebktv. helyes értelmezése esetén a panaszostól vagy a felperestöl nem követelhető meg az elszenvedett hátrány és a védett tulajdonság közötti oksági kapcsolat fennálltának bizonyítása, de álláspontunk szerint valószínüsítése sem, hiszen a korábbi említett megdönthető vélelem éppen az ok-okozati összefüggés fennálltának egyértelmüsítésére szolgál.

Az állásfoglalás utal arra, hogy ez a megközelítés kifejezetten szigorú, és egyértelműen a sérelmet szenvedett fél érdekeit tartja szem előtt. A bizonyítási szabályok ugyanis a már többször említett megdönthető vélelemböl indulnak ki, és ez alapján a munkáltató kimentési lehetőségei valóban korlátozottak. ${ }^{23}$

Utóbbi rigorózus megközelítés kapcsán szerepeljen itt példaként egy viszonylag friss határozat az Egyenlő Bánásmód Hatóság gyakorlatából. A 470/2014. számú döntésében kifejezetten azt mondja ki a Hatóság, hogy a munkáltató kimentési bizonyitása abban az esetben is sikertelen, ha nem tudja megcáfolni az ok-okozati összefüggést a panaszos munkavállaló által valószínüsitett védett tulajdonság és hátrány között. Vagyis ez a fajta jogértelmezés egyik oldalról nem várja el a panaszostól - vagy felperestől - az oksági kapcsolat semmilyen szintű igazolását, másik oldalról pedig kifejezetten rendelkezik az eljárás alá vont - vagy alperes - azon bizonyítási lehetőségéröl, amellyel ezt megcáfolni van lehetősége. Nézetünk szerint az Ebktv. 19. §-ának ilyen irányú értelmezése kifejezetten elöremutató, azonban a bírói gyakorlatba nehezen transzportálható jogkövetkeztésekre épül. ${ }^{24}$

\section{A fragmentált bírói gyakorlat elemzése}

A kúriai jogértelmezés kapcsán a legföbb kérdés az, hogy mennyiben alkalmazzák a bíróságok az Egyenlő Bánásmód Hatóság által kialakított szigorú jogértelmezést, hiszen ha azt nem vallják teljes mértékben magukénak, akkor szükségszerüen eltolódik a bizonyítás hangsúlya. Előzetesen feltételezhető, hogy a kúriai gyakorlat nem követi következetesen a fentebb kifejtett elvek és módszerek által definiált irányvonalat, hiszen a bírói gyakorlatban jellemzőbb az a megoldás, hogy a bizonyítási teher egyensúlyát igyekszik fenntartani a gyakorlat, vagyis kevésbé veszi figyelembe a felperes számára kedvezőbb elöírásokat. A következetes bírói gyakorlat el-

23 További korlátot képeznek az Ebktv. 22. §-ában foglalt speciális kimentési szabályok, ugyanis a munkáltatónak a foglalkoztatással kapcsolatos speciális szabályok alapján is csak szűk keretek között van lehetősége kimenteni magát.

${ }^{24}$ E nehéz transzportálhatóság a speciális bizonyítási szabályok jogi természetével magyarázható, hiszen az érdemben eltér a bizonyítás általános szabályaitól. 
fogadja az Ebktv. 19. §-ában foglalt valószínűsítési szabályokat, azonban a hátrány valószínúsítése mellett a védett tulajdonság és a hátrány közötti ok-okozati összefüggés valószínüsítését is elvárja a felperestöl, ami álláspontunk szerint viszont nem következik az Ebktv. szabályaiból. Vagyis egyik oldalról megtartja a valószínűsítést mint felperesi kötelezettséget a bírói jogértelmezés, azonban annak terjedelmét az Ebktv.-töl eltérően állapítja meg. ${ }^{25}$

A következőkben a vonatkozó magyar bírósági ítéleteket két csoportra osztva tárgyaljuk, aszerint, hogy a bíróságok milyen mértékben követik a fentebb kifejtett jogértelmezést (vagyis az Ebktv. normáit, illetőleg az Egyenlö Bánásmód Hatóság gyakorlatát). A felosztás kapcsán érdemes azt is megemlíteni, hogy az ítéletek nem időrendi, hanem a fentebb tárgyalt logikai sorrendben kerülnek elemzésre, hiszen azok között kronológiai sorrendet a döntések mondanivalója alapján álláspontunk szerint nem lehet felállítani. Végeredményben az okozati összefüggés fennálltára vonatkozó, a felperest eröteljesebben, avagy kevésbé védő megközelítés ütköztetésére fókuszálunk a következőkben. ${ }^{26}$

A következő két alpontban az elemzés tárgyát azon ítéletek képezik, amelyek hüen reprezentálják a bírói gyakorlatban uralkodó kettősséget a felperesre nézve kedvező vagy éppen hátrányos jogértelmezés alapján.

\subsection{A bizonyítási teher felperesre nézve kedvező megosztása a bírói gyakorlatban}

A BH 255/2004. számon közzétett határozatban a Kúria a bizonyítási teher jelentőségét és annak - véleményünk szerint - helyes megosztását határozza meg a következőképpen. ${ }^{27} \mathrm{Az}$ első- és másodfokú bíróság azt állapította meg, hogy a felperes munkavállalónak kell tudnia bizonyítania azt, hogy öt egyenlő bánásmódhoz való jogában a munkáltató megsértette az alkalmazási feltételek kapcsán, és ezt neki kellő megalapozottsággal alá kell tudni támasztania. A bíróságok arra a következtetésre jutottak, hogy amennyiben ezt a munkavállaló nem tudja igazolni, akkor nem valósult meg hátrányos megkülönböztetés. A Kúria azonban helyesen értelmezte az akkor hatályos 97/80/EK irányelvet, és kimondta, hogy bár az általános szabályok szerint valóban a munkavállalónak kellene bizonyítania a jogsérelmet, azonban az egyenlö bánásmód megsértése olyan különleges helyzetet, kapcsolatot teremt a peres felek között, hogy az általános szabály nem lesz alkalmazható. Az irányelv célja ezzel összefüggésben éppen az, hogy megkönnyítse a munkavállaló helyzetét, és biztosítsa azt, hogy a munkavállaló véletlenül se a bizonyítási nehézségek

25 BoDA Zoltán: Az egyenlö bánásmód megsértésének elbírálása. Ügyvédek Lapja, 2014/2, 31-32.

${ }^{26}$ Elözetesen megjegyzendő az is, hogy szintén csoportosítási szempont lehetne, hogy az adott határozatot a Kúria I-es, II-es, vagy III-as számú munkaügyi tanácsa hozza-e meg, de kutatásaim során e vonatkozásban is arra a következtetésre jutottam, hogy még ez sem tekinthető kizárólagos elhatárolási szempontnak, így mindenképpen szükséges ragaszkodni az imént említett kettéosztáshoz. Az elemzés tárgyát a következő két alpontban azon ítéletek képezik, amelyek hủen reprezentálják a bírói gyakorlatban uralkodó kettősséget.

27 Hasonló következtetésre jutott a Kúria Mfv.l.11.166/2010/7., Mfv.l.10.667/2010/38., Mfv.l.11.113/2009/3. és Mfv.l.10.642/2004/3. számú ítéleteiben. 
miatt essen el a megfelelő jogorvoslattól. A munkavállaló szemszögéből szinte lehetetlen lenne valamennyi releváns tényt és adatot feltárni, ezzel pedig aránytalanul hátrányos helyzetbe hozná őt a bíróság. A munkáltató ezzel szemben rendelkezik valamennyi releváns adattal, és van tudomása a fontos körülményekröl, így pedig rá lehet arra kényszeríteni, hogy valóban az összes körülményre kitérjen, mert ezáltal lehetősége lesz mentesülni a diszkrimináció miatti felelősség alól.

A KGD 5/2013. számú közigazgatási döntvényében a Kúria szintén az Ebktv. 19. $\S$-ával összhangban értelmezi a szabályokat, és megerősíti, hogy az egyenlő bánásmód megsértése miatt indított eljárásokban valójában a sérelmet szenvedett fél valószínüsitési kötelezettsége áll szemben a jogsértő fél bizonyítási kötelezettségével, utóbbi eredményessége esetén pedig a jogsértő fél sikerrel mentheti ki magát. Az ítélet csupán megemlíti az Ebktv. 19. §-át, utalva arra, hogy a bizonyítási teher speciálisan alakul az ilyen tárgyú ügyekben, hiszen az Ebktv. szerinti bizonyítási szabályok kétségkívül kedvezőbbek a diszkriminációval sújtott személyre nézve, és azok természetesen alkalmazandók az egyenlő munkáért egyenlő bér elv vélt vagy valós megsértése miatt kezdeményezett hatósági vagy bírósági eljárásban is.

A fentebb kifejtett gondolatmenetet következetesen követi a Kúria egy későbbi itéletében, ${ }^{28}$ a bizonyítási teher megosztása és megfordulása mellett hangsúlyozva, hogy a sérelmet szenvedett fél valószínűsítési kötelezettsége nem terjed ki a védett tulajdonság és az elszenvedett hátrány közötti oksági kapcsolat igazolására. E következtetés álláspontunk szerint azért különösen fontos, mert ez nem feltétlenül következik az eddig kifejtettekböl. A legfőbb kritika, ami a bizonyítási szabályok bírói gyakorlatban történő értelmezésével szemben megfogalmazható, éppen a valószínúsítési kötelezettség túlzott mértékủ kiterjesztése, vagyis az, hogy a munkavállalónak további - az Ebktv.-ben nem szereplő - tényeket is valószínüsítenie kell, más esetben a bíróság nem találja megfelelő szintűnek azt. Alátámasztja ezt az is, hogy a munkáltató - kimentési bizonyítása körében - minden további nélkül igazolhatja azt, hogy oksági kapcsolat nem áll fenn, vagyis indokolatlan lenne annak bizonyítására a munkavállalót kötelezni.

\subsection{Valószínüsítés és bizonyítás a bírói gyakorlatban - a diszkrimináció áldozatának hátrányára}

A feldolgozott ítéletek aránya is hủen tükrözi a bírói gyakorlatban meglévő ellentmondásokat, ugyanis az előző alponttal ellentétben számos olyan kúriai döntést találunk, amelyek az eddig kifejtettekkel ellentétesen, vagyis gyakorlatilag a felperes hátrányára értelmezik az Ebktv. 19. §-ában foglaltakat. Ennek megfelelöen a következőkben ezeket a döntéseket állítjuk szembe az eddig leírtakkal.

Fontos megállapításokat tesz a Kúria a KGD 10/2011. számú döntésében a bizonyítási szabályok kapcsán, értelmezve az Ebktv. 19. §-ában foglaltakat. A döntés értelmében a felperesnek kell tudnia valószínüsíteni a védett tulajdonság és az elszenvedett hátrány közötti ok-okozati összefüggést, és ezen valószínüsítést követö-

28 Lásd: Mfv.l.10.646/2012/4. 
en lehet helye a munkáltató oldalán az Ebktv. szerinti kimentésnek. A Kúria szerint ezen oksági kapcsolat fenn nem állta esetén a hátrányos megkülönböztetés bármely formája ${ }^{29}$ miatti marasztalás alaptalan, tekintve, hogy az nincs összhangban az Ebktv. 19. §-ával.

Az itéletben foglaltak ezen a ponton több szempontból is kritika tárgyává tehetők. Egyik oldalról az Ebktv. 8. és 19. §-ából sem következik az, hogy az oksági kapcsolatot a munkavállalónak kell legalább valószínüsítenie, mely értelmezés álláspontunk szerint nem helytálló, ugyanis ezzel a valószínúsítés gyakorlatilag bizonyítássá transzformálódna. ${ }^{30}$ Másik oldalról pedig az ok-okozati összefüggés bizonyítottsága szorosan összekapcsolódik az összehasonlítható helyzet fogalmával, márpedig hátrányos megkülönböztetés kizárólag összehasonlítható helyzet fennállta esetén állapítható meg. Ilyen módon, ha a diszkriminációval sújtott munkavállaló összehasonlítható helyzetben van a diszkriminációval nem sújtott többi munkavállalóval, akkor az oksági kapcsolat gyakorlatilag fennáll. Ennek magyarázata az, hogy mivel a védett tulajdonságot és a hátrányt köteles valószínüsíteni a munkavállaló, ezek sikeressége esetén van csak helye munkáltatói kimentésnek, melynek keretei között pedig bizonyíthatja, hogy nem áll fenn összehasonlítható helyzet, illetőleg a hátrány nem a védett tulajdonságon alapul. Megjegyzendő, hogy a felperesnek az összehasonlítható helyzetet nem kell valószínüsítenie, hanem mindössze meg kell jelölnie azon munkavállalót vagy munkavállalókat, akikkel ő összehasonlítható helyzetben van. ${ }^{31}$ Vagyis a sikeres munkavállalói valószínűsítés eredménye az is, hogy az oksági kapcsolat fennálltát - tekintettel az összehasonlítható helyzetre - vélelmezni kell, hiszen ha az összehasonlítható helyzetben lévő többi munkavállaló nem szenvedte el a hátrányt, akkor a hátrány oka logikusan csak a védett tulajdonság lehet. Álláspontom szerint ezt „bele kell érteni” a bizonyítási szabályokba, ugyanis ellenkező esetben parttalanná válna a bizonyítási teher megosztásának fő szabálya, hiszen a munkavállaló nem tudja azt bizonyítani, hogy védett tulajdonságára tekintettel érte őt a megjelölt hátrány.

A Kúria álláspontja szerint önmagában véve az, hogy a panaszos munkavállaló rendelkezik a megjelölt védett tulajdonsággal, és sikerrel valószínűsíti, hogy hátrány érte, még nem elegendő ahhoz, hogy diszkriminációt lehessen megállapítani. A Kúria álláspontja szerint a panaszos munkavállalónak alaposabban kellett volna bizonyítania ${ }^{32}$ azt, hogy védett tulajdonsága és a hátrány között oksági kapcsolat áll fenn, ez pedig nem történt meg a valószínüsitésen túli bizonyitékokkal. Vagyis

29 Kivételt képez ez alól a megtorlás, ugyanis az Ebktv. 10. § (3) bekezdésében foglalt meghatározás szerint az oksági kapcsolatnak nem a panaszos védett tulajdonsága és az elszenvedett hátrány között, hanem a diszkriminációval szembeni kifogás vagy fellépés és az abból származó jogsérelem között kell fennállnia. Lásd MAGICZ András: A megtorlással szembeni védelem gyakorlati kérdései és a jogi szabályozás továbbfejlesztésének irányai. In: Majtényi (szerk.): i. m., 167-168.

30 Lásd az Egyenlő Bánásmód Hatóság már említett 470/2014. számú határozatát, amely szerint sikertelen a munkáltató kimentése akkor, ha nem tudja megcáfolni a munkavállaló által elszenvedett hátrány és a munkavállaló védett tulajdonsága közötti ok-okozati összefüggést.

31 FARKAS Lilla: Getting it right the wrong way? The consequences of a summary judgment: the Meister case. European Anti-Discrimination Law Review, 2012/15, 24.

32 Vagy igazolnia, de a valószínüsitésnél mindenképpen „meggyőzőbben” kellett volna állításait alátámasztania. 
a Kúria szerint - ellentétben az Ebktv.-vel - a panaszosnak nem elegendő indirekt módon valószínüsítenie az oksági kapcsolatot, hanem azt bizonyítani is kell tudnia. A bizonyítás pontosságára és további kritériumaira vonatkozóan alaposabb eligazítást nem ad a Kúria, csak az ítélet megfogalmazásából lehet arra következtetni, ${ }^{33}$ hogy a Kúria elvárása az a panaszossal szemben, hogy olyan bizonyítást terjesszen elö, amire a munkáltató érdemben tud ellenbizonyítással reagálni.

A Kúria szerint továbbá a Hatóságnak ahhoz, hogy megalapozottan állapítsa meg a diszkriminációt, azt kellett volna az okozati összefüggés kapcsán vizsgálnia, hogy vajon valóban védett tulajdonsága miatt nem foglalkoztatta-e a megfelelő munkakörben a panaszost munkáltatója. Ezt álláspontja szerint azzal lehet alátámasztani, hogy tudni kell igazolni azt, hogy a munkáltató azért nem foglalkoztatta tovább eredeti munkakörében a kérelmező munkavállalót, mert anyasága miatt kételkedik abban, hogy munkáját változatlan színvonalon tudja szülés utáni újbóli munkába állását követően is ellátni. A Kúria szerint az oksági kapcsolat csak akkor áll fenn, ha az ilyen jellegü mögöttes, bújtatott okok mentén valósul meg a hátrány, ha pedig ilyen jellegủ további ok nem mutatható ki, akkor a panaszos valószínúsítése - bizonyítása? - nem eredményes, vagyis a munkáltató ki tudja menteni magát. Megjegyzi továbbá, hogy a védett tulajdonság és a hátrány egyidejü fennállása önmagában még nem jelenti azt, hogy a munkáltató diszkriminatívan járt el, utóbbi igazolásához ugyanis „valódi” okozati összefüggés szükséges. Ha ez hiányzik, akkor a munkáltató kimentésének sikeresnek kell lennie.

Álláspontunk szerint utóbbi megállapitások nem egyeztethetök össze az Ebktv. szemléletével, ${ }^{34}$ az annak alapját képező uniós normákkal és az egységes hatósági gyakorlattal sem, ${ }^{35}$ továbbá aggályokat vet fel az egységes bírói gyakorlat kialakitása kapcsán is. ${ }^{36}$ Ha ugyanis ilyen módon kerül értelmezésre az Ebktv. 19. §-a, akkor lényegében éppen az az előny vész el a sérelmet szenvedett fél oldalán, amellyel a jogszabály szerint nem bizonyítania, hanem pusztán valószínűsítenie kell az elszenvedett hátrányt és a védett tulajdonságot, valamint okafogyottá válik a korábban már bemutatott vélelem az egyenlő bánásmód munkáltató általi megsértésével összefüggésben. Megítélésünk szerint a hátrány és a védett tulajdonság egyidejü fennálltánál alaposabban a munkavállaló nem tudja alátámasztani a diszkrimináció megvalósulását, hiszen nem egyértelmü, hogy ezen túl mi várható még el tőle. A munkavállalónak nem áll módjában például statisztikákkal, kimutatásokkal, hivatalos iratokkal igazolni az ok-okozati összefüggést, ${ }^{37}$ így ebben az esetben gyakor-

${ }^{33}$ „A beavatkozó (a hatósági ügy panaszosa) a Hatóság rendelkezésére bocsátott iratokkal a foglalkoztatási jogviszonnyal kapcsolatos hátrány meglétét kellően valószínűsítette, továbbá nyilatkozott arról is, hogy álláspontja szerint az anyasága, azaz a védett körbe tartozó tulajdonsága miatt kellett a hátrányt elszenvednie. A beavatkozó a védett tulajdonság és a hátrány közötti okozati összefüggést bizonyítékokkal - így levéllel, tanúkkal stb. - nem erösítette meg." Vagyis a Kúria egyértelmüen többet vár el az Ebktv. szerinti valószínüsítésénél.

${ }^{34}$ FARKAS Lilla-KÁDÁR András Kristóf-KÁRPÁTI József: Néhány megjegyzés az egyenlő bánásmódról szóló törvény koncepciójához. Fundamentum, 2003/2, 123-125.

35 Lásd a 384/4/2008. (III. 28.) TT. sz. állásfoglalást.

36 Értve ezalatt a döntés BH 255/2004. számú ítélettel ellentétes voltát.

37 Lásd: C-415/10. sz., Galina Meister kontra Speech Design Carrier Systems GmbH ügy (ECLI:EU:C:2012:217). 
latilag lehetetlen lenne az eredményes valószínűsítés, szemben a munkáltatóval, akinek sokkal több lehetősége van igazának alátámasztására ebben a körben. ${ }^{38}$

A kauzalitás bizonyitásával összefüggésben fontosnak tartom megemlíteni, hogy a Kúria egy viszonylag friss ítéletében ${ }^{39}$ a munkavállaló hátrányára döntött a következők szerint. A Kúria a bizonyitási terhet az Ebktv. 19. §-a szerint osztotta ki, majd a felperes keresetét azért találta alaptalannak, mert álláspontja szerint a felperes nem tudta valószínüsíteni, hogy az elszenvedett hátrány a valószínüsített védett tulajdonságára tekintettel következett volna be. Vagyis az Ebktv. 19. § (1) bekezdése szerinti sikeres valószínüsítés ellenére nem kerülhetett sor a munkáltató kimentési bizonyítására, mert a döntés szerint a védett tulajdonság és az elszenvedett hátrány között ok-okozati összefüggésnek kell fennállnia, amit szintén a felperesnek kell tudnia valószínúsíteni. Nézetünk szerint, amennyiben a Kúria a megjelölt testületek állásfoglalásával megegyező tartalmú egységes jogértelmezést fogadna el, akkor okfejtésének a sikeres felperesi valószínüsítéssel véget kellene érnie, és rá kellene térnie az alperes munkáltató kimentési bizonyításának vizsgálatára. Mindez úgy is megfogalmazható, hogy a Kúria egy olyan további feltételt szab a felperesi valószínüsítés sikerességének, ami nem szerepel az Ebktv.-ben. Következtetésként levonható, hogy a bírói gyakorlat egy jelentős szegmensében az oksági kapcsolat valószínüsítése vagy bizonyítása többletkövetelményként van jelen az Ebktv. 19. § (1) bekezdésében foglaltakhoz képest a felperes oldalán. ${ }^{40}$

A kúriai gyakorlat további vitatható eleme a felperes részére bizonyítási kötelezettség elöírása, ${ }^{41}$ amely alapjaiban véve ellentétes az Ebktv. 19. $§(1)$ bekezdésében foglaltakkal. Bár az ítélet az akkor hatályos 1992. évi Mt. 5. § (8) bekezdésére utal a bizonyítási szabályok körében, de mivel azok lényegüket tekintve megegyeznek az Ebktv. jelenleg hatályos szabályaival, ezért álláspontunk szerint az ítéletben kifejtettek a jelenleg irányadó joggyakorlat részét képezik.

A Kúria egyik döntése szerint a bizonyítási teher egyensúlyát a diszkriminációs ügyekben is szükséges fenntartani, így kifejti, hogy az egyenlö bánásmód elvére történő hivatkozás önmagában nem elegendő a munkavállaló oldalán ahhoz, hogy a bizonyítási teher automatikusan átforduljon, és az a munkáltatót terhelje. Erre tekintettel a munkavállalónak kötelessége elsőként azt bizonyitani, hogy hátrány érte, ${ }^{42}$ ezt követöen lehet csak helye kimentési bizonyitásnak. E nézőpont véleményünk szerint ellentmondásos, hiszen egyik oldalról épít a bizonyítási teher megfordulásának szabályára, másik oldalról viszont hangsúlyozza a diszkriminációra hivatkozó fél olyan kötelezettségét, ami nem vezethető le az Ebktv.-ből.

38 PALMeR: i. m., 23-25.

39 Mfv.ll.10.064/2014/3.

40 Ezzel összefüggésben meg kell említeni a Kúria Mfv.ll.10.112/2013/3. számú ítéletét is, amely szerint a felperes védett tulajdonságának megléte önmagában nem alapozza meg a hátrányos megkülönböztetés megállapítását, annak bekövetkeztét „igazolnia” kell tudni a felperes munkavállalónak. Véleményünk szerint ez a fajta jogértelmezés is ellentétes az uniós joggal és az Ebktv.-vel egyaránt, hiszen a védett tulajdonság és a hátrány megléte esetén semmilyen további „igazolási” kötelezettség nem írható elő a felperes számára.

41 Mfv.l.10.369/2008/8.

42 Illetve a védett tulajdonságot is. 
Hasonlóan aggályosnak és vitathatónak ítéljük a Kúria Mfv.II.10.480/2013/3. számú itéletében kifejtetteket, ugyanis e szerint kellő bizonyítottság hiányában a felperes valószínüsítése eredménytelen, ez pedig mintegy „kiváltja” a munkáltató kimentési bizonyítását. Ez az értelmezés még az Ebktv.-ben foglaltaknál is szigorúbb, azonban ez a szigor a munkavállaló oldalán jelentkezik. Önmagában az, hogy valószínűsítés helyett bizonyításról rendelkezik a Kúria, sem egyeztethető össze az Ebktv.-beli szabályok rendeltetésével, az pedig, hogy kellö bizonyítottság hiányában a Kúria kizárja a diszkrimináció megvalósulását, eleve aggályosnak tűnik. Elsősorban azért, mert ezzel a Kúria nem a korábban említetteknek megfelelően mintegy kiegyenlíteni kívánja a felekre nehezedő bizonyítási terhet, hanem kellő bizonyítottság hiányában azt a könnyebbséget is megadja a munkáltatónak, hogy érdemi bizonyítást ne terjesszen elő. Ez a fajta jogértelmezés azért kritizálható, mert az irányelvi szabályokból tisztán kivehető, hogy a bizonyítási szabályok kulcsmomentuma a munkáltató kimentése, vagyis ebből a szempontból indokolatlan és alaptalan azt eleve kizárni, hiszen az irányelvi előírások szerint a munkáltatónak „csak” magát kimenteni van lehetősége.

Nem egyértelmü továbbá a felperesi valószínüsítés tartalma sem a bírói gyakorlatban, EBH 2014. M.19. számú elvi határozatában ugyanis a Kúria a felperes igazolási kötelezettségéről rendelkezik a bizonyítási eljárás során, ami azért megkérdőjelezhetö, mert igazolás és valószínüsítés jogi tartalma jelentős mértékben különbözik egymástól. ${ }^{43}$ Álláspontunk szerint célszerü lenne a bírói gyakorlatban is tisztázni az ilyen típusú dogmatikai kérdéseket. A Kúria a bizonyítási teher megosztásával összefüggésben még egy figyelemre méltó megállapítást tesz, ugyanis a felperes sikertelen valószínűsítése ellenére kötelezte az alperes munkáltatót a kimentési bizonyításra, méghozzá - tartalmilag - az Ebktv. 22. §-a alapján. Utóbbi momentum kritika tárgyává tehető, ugyanis az Ebktv. 19. §-a csak a munkavállaló sikeres bizonyítása esetére rendeli alkalmazni a munkáltatói kimentési bizonyítás szabályait, vagyis ilyen módon nem a jogszabállyal összhangban osztotta ki a Kúria a bizonyítási terhet. Így megjegyzendő, hogy a bizonyítási eljárás első szakaszának sikertelensége esetén valójában sor sem kerülhetne a másodikra, az alperes kimentési bizonyítására, hiszen fogalmilag lehetetlen olyan körülmények alól kimentenie magát, amelyeket a munkavállaló nem tudott az Ebktv.-nek megfelelően valószínüsíteni. ${ }^{44}$

Szintén a felperes valószínüsítési kötelezettségének tartalma vonatkozásában kell szólni a Kúria Mfv.l.10.093/2014/6. számú döntéséről, amelyben a Kúria rögzíti a felperes valószínüsítési kötelezettségét, az Ebktv.-nek megfelelően kijelölve annak terjedelmét, de emellett az alperes kimentési bizonyítását szükségtelennek tartja arra tekintettel, hogy a felperessel szemben hátrányos megkülönböztetés nem állapítható meg az alapján, hogy „fiatal, nyelvvizsgával rendelkezik és felsőfokú tanulmányokat folytat". Véleményünk szerint a Kúria e vonatkozásban nem megfe-

43 Az Egyenlő Bánásmód Tanácsadó Testület 384/4/2008. (III. 28.) TT. sz. állásfoglalása szerint valószínűsítés alatt olyan bizonyítást (igazolást) kell érteni, mely alapján az átlagember azt a következtetést vonja le, hogy objektív megítélés alapján a kérelmező panasza alapos. Megállapítható tehát, hogy a munkáltatót terhelő bizonyítási kötelezettséghez képest minőségi különbség áll fenn e tekintetben a bizonyítási eljárás e két cselekménye között, ennek pedig különösen nagy jelentősége van a diszkriminációs ügyekben.

44 GYulaVÁrI (2014): i. m. 
lelően alkalmazta az Ebktv. 19. §-át, ugyanis vagy már eleve a felperes valószínüsitését kellett volna eredménytelennek nyilvánítani védett tulajdonság hiányában, vagy pedig a valószínűsítés sikeressége esetén érdemben le kellett volna folytatni az alperest terhelö bizonyítási eljárást. Végeredményben pedig legalább a felperes fiatal kora értékelhető lett volna védett tulajdonságként, következésképpen a valószínüsítést sikeresnek kellett volna tekinteni.

\section{Következtetések}

Visszatérve a címben vázolt alapproblémára, az a kérdés is feltehetö, hogy a bizonyitás valójában melyik fél terhe a joggyakorlatban. A fentiek alapján az a válasz adható, hogy az európai uniós jog szerint egyértelmüen a munkáltatóé, az Ebktv. szerint a munkáltatóé, az Egyenlő Bánásmód Hatóság szerint nagyobb részt a munkáltatóé, míg a birói gyakorlat szerint inkább a munkavállalóé. Ebből is világosan látszik, hogy a bizonyítási teher megfordulásának megítélése nagymértékben eltér a hatósági és a bírósági gyakorlatban. Az ellentétes megítélés azért hordoz magában különösen nagy veszélyt, mert az Ebktv. 19. §-ának nem megfelelő értelmezése lényegében aláássa az egyenlő bánásmód körében ismert kulcsfogalmak hatékony alkalmazását, amellett, hogy az egyébként is bonyolultan megfogalmazott kimentési szabályok értelmezését sem könnyíti meg. ${ }^{45}$

A sérelmet szenvedett fél szempontjait elsődlegesen szem előtt tartó, speciális, kedvezményes bizonyítási szabályok az Ebktv.-ben - összhangban az irányelvi elöírásokkal ${ }^{46}$ - egyértelmüen megjelennek. A kedvezményes szabályok azonban nem azt jelentik, hogy a felperesnek vagy a panaszosnak elég egyszerüen hivatkoznia a sérelemre, hanem valószínűsítési kötelezettsége van, ami ezt követően majd szemben áll az eljárás alá vont bizonyítási kötelezettségével. Helyesebb talán ezt úgy megfogalmazni, hogy legalább valószínüsítenie kell tudnia a panaszosnak a sérelmét, de saját helyzetét könnyíti meg, ha a valószínűsítés keretei között akár bizonyítani is tud. Erre természetesen nem köteles, és nem is kötelezhető az eljárás során.

A bizonyitással összefüggésben célszerü volna az Ebktv. és az Egyenlő Bánásmód Hatóság szigorú megközelítéséhez ragaszkodni, azonban a kimentési szabályok alkalmazását összhangba kellene hozni a bizonyítás szabályaival. A foglalkoztatás kapcsán továbbá fontos, hogy a kimentés valóban csak olyan objektív szempontokra épüljön, melyek a munka természetéből szükségszerüen következnek és lényegesek.

Az összehasonlítható helyzetre vonatkozó bizonyítás természetesen elengedhetetlen, de mivel az összehasonlítható helyzet fennálta magában hordozza álláspon-

45 GyulaVÁRI Tamás: A kimentési szabályok harmonizációja: elveszett jelentés? Csak a húszéveseké a világ? Az életkoron alapuló diszkrimináció tilalma a magyar és az uniós jogban (konferencia), Nemzetközi Tudományos Konferencia az Osztrák-Magyar Akció Alapítvány támogatásával és a Magyar Munkajogi Társaság szakmai támogatásával. Pázmány Péter Katolikus Egyetem Jog- és Államtudományi Kar, Budapest, 2014. 12. 11.

46 2000/78/EK irányelv 10. cikk (1) bekezdés, a 2000/43/EK irányelv 8. cikk (1) bekezdés és a 2006/54/EK irányelv 19. cikk (1) bekezdés. 
tunk szerint az ok-okozati összefüggés fennálltát is, ezért utóbbi felperes vagy panaszos általi bizonyítása, de akár valószínüsitése is indokolatlannak tünik az Ebktv. 19. § (1) és (2) bekezdése alapján. ${ }^{47}$ Azért is lenne ez indokolatlan, mert az (1) bekezdés a) pontja a hátrány és védett tulajdonság egyidejü fennálltát írja elő, márpedig ez gyakorlatilag az összehasonlítható helyzetet jelenti. Ezzel ellentétesen: az alperesnek kell tudnia igazolnia azt, hogy a felperes helyzete nem összehasonlítható, vagy azt, hogy nem áll fenn kauzalitás a valószínüsített védett tulajdonság és az elszenvedett hátrány között. Mindennek további magyarázata lehet az is, hogy mind az összehasonlíthatóság kritériuma, mind pedig az oksági kapcsolat bizonyítási kérdés, vagyis a felperes vagy panaszos sikeres valószínüsítését követő kimentési bizonyítás körébe kell essen. Álláspontunk szerint ez az Ebktv. 19. § (2) bekezdés a) és b) pontjából következik, hiszen mivel a munkáltatónak csak kimentési bizonyítás keretei között van lehetősége igazolni azt, hogy megtartotta az egyenlö bánásmód elvét, ezért természetszerüleg bizonyításával eredményesen kell tudnia „ellent mondania" a felperes valószínűsítésének. Ugyanakkor az összehasonlítható helyzet fogalmát, elemeit - mivel ez jogalkalmazási kérdés - célszerütlen lenne az Ebktv.-ben szabályozni, helyette indokolt lehetne az Ebktv. 19. § (2) bekezdésében utalni a kauzalitásra. Az a) pontba beilleszthető lenne az a kitétel, hogy „vagy a védett tulajdonság és az elszenvedett hátrány közötti ok-okozati összefüggés hiányát", ugyanis álláspontunk szerint mivel az a) pont jelenleg csak utóbbi kettöre vonatkozik, ezért a jogalkalmazó helyzetét jelentős mértékben meg lehetne ezzel könnyíteni, és ezáltal egységesebbé tenni a joggyakorlatot.

Végezetül érdemes röviden kitérni arra is, hogy a kúriai joggyakorlat látványos fragmentáltsága, illetőleg a hatósági jogértelmezéshez képest eltérő irányvonalai milyen okokra vezethetők vissza. Álláspontunk szerint ezen indokok nagyon nehezen tárhatók csak fel, és talán még az elemzett döntésekböl sem olvashatók ki.

Korábban már említettük, hogy a kronológiai fejlődést vagy a különböző kúriai tanácsok olykor eltérő ítélkezési gyakorlatát alapul véve sem biztos, hogy megtaláljuk eme eltérések okait, így azokat máshol is keresnünk kell. Nézetünk szerint az Ebktv. 19. §-ában foglalt szabályok bonyolultsága mindenképpen szerepet játszik ebben, de ugyanígy a bíróságok feltételezhető idegenkedése is e különös szabályoktól. ${ }^{48}$ Természetesen előbbi kapcsán felvethetők koncepcionális megoldási javaslatok, utóbbi kapcsán pedig nehéz megtalálni eme távolságtartás valódi okait. Teljesen világos ugyanakkor az is, hogy addig, amíg az Európai Unió Bírósága sem tud egységes jogfejlesztő gyakorlatot kialakítani e kérdésben, addig ez a tagállami bíróságoktól is csak nehezen várható el. ${ }^{49}$

Persze a magyar bíróságoknak megfelelő mintául kellene hogy szolgáljon az Egyenlő Bánásmód Hatóság joggyakorlata, azonban ez az érv is kivédhető a bíróságok részéröl azzal, hogy a két eljárás közötti alapvető különbségek csak nehezen teszik ezt lehetővé, sőt akár a bíróság előtti eljárások hatékonyságának csökkenése

47 Farkas ugyanezt hangsúlyozza a releváns európai bírósági esetjoggal összefüggésben. Lásd FARKAS: i. m., 25.

48 Lásd BodA: i. m., 31-32.

49 Így például nem egységes az európai bírósági esetjogban sem a valószínűsítés tartalmának és eszközeinek, vagy akár az ok-okozati összefüggés bizonyításának módszere sem. 
is felvetődhet. Persze ez mind csak feltételezés, de álláspontunk szerint ez is jól példázza azt a szabályozásbeli és szemléletbeli komplexitást és bizonytalanságot, ami a speciális bizonyítási szabályokat övezi a diszkriminációs ügyekben.

A bíróságok minden bizonnyal kevésbé tartják „szívügyüknek” az egyenlő bánásmód védelmét, föként ilyen radikális bizonyítási szabályokra tekintettel. Hiszen míg az Egyenlő Bánásmód Hatóság létének mintegy záloga a diszkriminációval szembeni küzdelem jogi garanciáinak minél magasabb fokú, és minél inkább az áldozatvédelemre fókuszáló érvényre juttatása, addig ez a szemlélet a bírói gyakorlatból hiányzik. E szemlélet átvételének hiánya bizonyos fokig számon kérhető a bíróságokon, de túlzás lenne azt elvárni, hogy az egyenlő bánásmód megsértésével kapcsolatos ügyek kiemelt figyelmet kapjanak a bírósági eljárások körében. Persze ez a probléma úgy is orvosolható lenne, ha a Kúria e tárgykörben elvi határozati szinten foglalna állást az Ebktv. szerinti bizonyítási szabályok radikális, áldozatvédő értelmezése mellett.

\section{Zárógondolatok - a bizonyítás valódi terhe}

Álláspontunk szerint érezhető valamiféle sajátos, láthatatlan „háttértendencia” vagy egyfajta természetes motiváció a bíróságok részéröl arra nézve, hogy a fordított bizonyitást ne tudják következetesen alkalmazni. Eme szembenállás nehezen magyarázható, és még nehezebben megindokolható, azonban azt sem szabad elfelejteni, hogy a diszkrimináció hiányának bizonyítása valóban nehézkesnek tünik az elméletben és a gyakorlatban egyaránt. Viszont, ha figyelmesen áttanulmányozzuk az Egyenlő Bánásmód Hatóság gyakorlatát, akkor azt látjuk, hogy talán a kiindulóponttal van a baj, hiszen a hatósági gyakorlatban nem hat természetellenesnek és ellentmondásosnak az irányelvi szabályoknak megfelelö törvényi normák alkalmazása. Ennek az oka minden bizonnyal az, hogy a magyar bírói gyakorlatból hiányzik az egyenlő bánásmód elv védelmének prioritása mint alapvető szempont, így pedig a bizonyítási szabályok is kvázi sablonszerüen, nem pedig azok logikája és szellemisége szerint kerülnek értelmezésre és alkalmazásra. Vagyis végeredményben arra a következtetésre kell jutnunk, hogy a bírói gyakorlat csak korlátozott mértékben juttatja érvényre az áldozatvédelem elvét a diszkriminációs ügyekben, márpedig véleményünk szerint a (foglalkozási) diszkriminációval szembeni küzdelem nem lesz addig igazán sikeres a magyar jog keretei között, amíg a bíróságok nem alakítanak ki egy, az Egyenlő Bánásmód Hatóság gyakorlatával összhangban lévő értelmezést. Addig csak „féloldalas” áldozatvédelemröl beszélhetünk.

\section{Abstract}

This paper emphasizes one of the most important questions of equal treatment that is the reversed burden of proof and aspects of the special sharing of burden of proof. The hypothesis of the paper is the following: although the Hungarian regulation follows the relevant directives of the European Union properly, the legal practice 
does not focus on victim protection to the expected level. The legal practice of the Equal Treatment Authority and the Supreme Court (Curia) of Hungary are both analysed, therefore the different approaches can be confronted. The paper provides de lege ferenda proposals mainly in connection with the unification of the Hungarian judicial practice. 